\title{
THE REPETITIVE PHILOSOPHY OF ABSTRACTION IN NUBIAN FOLKLORE AND ITS ROLE IN ROOTING THE DESIGN IDENTITY
}

\author{
Amani Hamdy Fahim SANAD*
}

Department of Textile Printing, Dyeing and Preparation, College of Applied Arts, Helwan University, Egypt

\begin{abstract}
Nubia occupied - and still - humans and a site, a special place, especially the visible Nubian cultural heritage. Nubia has a huge folk heritage that is characterized by diversity and richness in decorations and colors, as well as the multiplicity of performance methods and so the multiplicity of methods and patterns of repetition. Whereas the Nubian artist possessed a repetitive philosophy in which he dealt with his units that he dealt with abstractly and as the abstract trend in art is one of the important directions whereby the abstract artist avoids simulating the elements, representing physical objects and abandoning most of their details and raises aesthetic responses to the formative relationships among spaces, dimensions and colors due to its artistic components, and the Nubian folklore is one of the most important folk heritage that confirm our Egyptian identity, and it occupies its place especially in the ancient and modern life of Egypt and Egyptians. Folk art has its own value stemming from its sincerity and originality, as it is a tapestry of the people's conscience and is passed on to generations. There are many methods of reading folk art from the creative point, as it is an art that combines realism, symbolism and abstractness that constitute its intrinsic value, the fundamental value inherent in folk art is its rhythm and its abstraction, it is represented in organic abstraction, where the shape carries among its folds the pulse of life in the nature of abstract shapes regardless of any visual meaning and its changing rhythm by changing its repetition methods and repetitive philosophy, and geometric abstraction is that which is consistent with many beliefs and ideas in different civilizations, but in the Nubian heritage it carries harmonies, especially when combined with each other, as it is also distinguished by the repetition of units with the simplification of shapes and their abstraction in organized lines that make them give an infinite rhythm. The importance of the research lies in the development of designs for women's fabrics with a new character that works to consolidate the identity and keeps pace with contemporary designs through the popular Nubian heritage, to develop innovative and renewed thinking in the field of textile printing in general and women's fabrics in particular

Keywords

Nubia, Folk Heritage, Abstract Symbols
\end{abstract}

\section{Introduction}

The Nubian folklore is one of the most important folk heritage that confirm our Egyptian identity, and it occupies its place especially in the life of Egypt and Egyptians, both ancient and modern, as it includes an Egyptian human group with special social, cultural and environmental characteristics. Nubians are a people who speak a local language and live on a land that forms the geographic region known as Nubia, half of which is located in the Arab Republic of Egypt, and the other half in the Republic of Sudan. This heritage represents important and influential values in our national heritage, as it is characterized by simplicity, innate nature and reliance on the surrounding environment, and preserving this popular heritage and reformatting it in a way that is in line with contemporary reality is the best way to confirm our cultural and Arab privacy.

\footnotetext{
* Corresponding author: appliedarts@a-arts.helwan.edu.eg
} 
Nubian folk is an art that combines realism with abstract symbolism that compose its core truth, as the core value inherent in folk art is its rhythm, abstraction and repetition, so all its units, terms and symbols appear in a repetitive and clear form bearing a special character of beauty. Whereas the Arab society falls within the families of the incoming foreign currents and ideologies that dominated the minds for a long time and obliterated our identity and the creativity resulting from ourselves and our culture was absent into processes of transmission and simulation that are inconsistent with our nature and our Arab personality, especially in the field of textile printing in general and the printing of women's residence in particular, this requires emphasizing and reviving the Egyptian folk heritage (Ibtisam Muhammad Abdel Wahab, 2014). Hence, the researcher sees the necessity of reviving the Nubian heritage through contemporary Egyptian designs that bear a character that confirms and establishes the identity.

\section{Research Problem}

The research problem lies in the lack of women's clothing fabrics that reflect the Egyptian identity, as the Nubian folklore is rich and full of units and abstract terms (including geometric and organic) with different repetitive systems that have the character of originality which prompted the researcher to think about creating designs for women's clothing fabrics that have the character of originality and contemporary at the same time, and reflect the Egyptian identity.

\section{Research Objectives}

1- Study the repetitive systems of abstract units in the heritage of Nubian folk art.

2- Creating contemporary designs for women's fabrics through repetitive systems and abstract units of Nubian folk art, and in turn work to root the identity.

\section{Research Significance}

1- Benefiting from the Nubian folk heritage in preparing a collection of women's clothing designs with an Egyptian character and in line with contemporary and modern global trends.

2- Opening new horizons for artistic expression and creativity through a return to the old cultural assets and our popular heritage and an attempt to adapt it to enrich the field of textile printing design.

\section{Research Hypothesis}

The research suggests the possibility of making use of the repetitive systems and abstract units of Nubian folk art to create contemporary designs for women's fabrics.

\section{Research Methodology}

- The Analytical Descriptive Method: In describing the abstract units and analyzing the 
repetitive patterns present in the Nubian folklore.

- Experimental Method: It's evident in the design experiment stages.

\section{Conceptual Framework}

\section{Nubia and its Geographical Location}

Nubia extends from Aswan waterfall to the city of Meroe near the fourth waterfall, and it's divided into two parts: Upper and Lower.

- The First: It is in Upper Egypt and extends from Aswan to the Egyptian border, a little to the south of Abu Simbel.

- The other: It is in the Republic of Sudan and extends hundreds of miles from the border village of Faras to the south of Dongola, where the Nile bends to the northeast.

The Egyptian Nubia region forms the lower part, as it is located in the far south of the Nile Valley and extends about $20 \mathrm{~km}$ south of Aswan, which is concerned with the study. The upper part is located in the country of Sudan, and we find that this country lived in isolation from the rest of the Nile Valley, so it retained its distinctive character (Hassan Fathy - 2001) which made it a very beautiful painting, each house in it is more beautiful than the other, its architecture has an attractive rhythm, and every house is uniquely decorated around the entrance with brickwork, prominent and linear decorations of clay, the folk arts in it have its own character and value stemming from its sincerity and originality.

\section{Results}

1. The study confirmed that the repetitive philosophy in the Nubian folk heritage and the aesthetic values and distinctive features it contains can be a source of confirmation on the originality of this heritage and the integrity of our identity.

2. The study showed the wide range of utilization of the repetitive systems of the decorations of the Nubian folklore to create designs suitable for women's clothing fabrics.

\section{Recommendations}

1. Deepening the idea of adhering to everything that expresses our Egyptian identity to reduce the demand for all that is imported.

2. Paying attention to studying the Nubian folklore and benefiting from it in various other applications with modern visions.

3. The need to pay attention to studies dealing with heritage and publish them at the local and global levels. 


\section{References}

1. Ibtisam Muhammad Abdel Wahab: "Factors Affecting the Methods of Egyptian Folklore from their Primary Sources to root Identity in Interior Design" - The International Design Journal - Volume Four, Issue 1 - 2014.

2. Hassan Fathy: "The Building of the Poor" - Third Edition - Al-Ain Publishing and Distribution House - Cairo - 2001.

3. Nahed Baba: "Nubian Decorations" - Waad for Publication and Distribution, 2010.

4. Sami Bakhit Abd Al-Salihin: "The Egyptian Folk Crafts Decorations between Heritage and Contemporary" - Egyptian General Book Authority, Cairo, 2012.

5. Hana Ahmed Muhammad Yassin: "Artistic Installations Inspired by the Unity and Symbols of Egyptian Folk Art" - The First International Conference of Minia University, 2009.

6. Ashraf Hussein Ibrahim: "The Authority to survive and transform the Egyptian Popular Formative Terms in the Internal Space" - The Sixteenth International Conference of Philadelphia, Jordan, 2012.

7. Yusef Khalifeh Ghorab, Najwa Hussein Hegazy: "The Aesthetics of Popular Decorations, a Vision for Developing Taste and Nurturing Emotion" - House of Arab Thought, Cairo, First Edition, 2009.

8. Noura Al-Sayed Al-Ashmouni: "Enriching the Decorative Design of Women's Outfit with a Mixture of Egyptian and Gulf Folklore" - PhD, Faculty of Specific Education, Mansoura University.

9. Rania El-Sayed Al-Arabi: "Designs for Upholstery Fabrics Printed with Morphology Values for Ceramic Art”.

10. Sahar Ahmad Ibrahim Mansour: The Jordanian Journal of Arts Volume VI, Issue Three, 2013.

11. Atasoy, Nurhan: "The Art of Islam", Flammarion, 1990.

12. Ray Faulkne, Edwin Ziegfeld: “Art Today” - New York, 1996.

13. Innemée, K.: "Observation on the System of Nubian Church Decoration" - Arkamani Sudan Electronic Journal of Archaeology and Anthropology- October 2005.

14. Ayat Abdullah FAWAZ, Dalia Mohamed Abdel Qader MAKKI, Nada Hussam El Din Mohamed KAMEL, Mohamed OSAMA, THE EDUCATIONAL PROCESS OF FURNITURE DESIGN BETWEEN MATERIAL AND SUSTAINABILITY, International Journal of Design and Fashion Studies, Vol. 3, No. 1, 2020, pp. 1-5.

15. Dalia Fouad Mahmoud ATTIA, THE IMPACT OF THE COLOR SCHEMES IN THE 
INTERIOR DESIGN ON SOME GROUPS OF SPECIAL NEEDS CHILDREN (AUTISM, HYPERACTIVITY AND DISTRACTION), International Journal of Design and Fashion Studies, Vol. 3, No. 1, 2020, pp. 6-9.

16. Dalia ABDEL MONEIM, Abeer Farouk Ahmed ALI, THE PLASTIC POTENTIAL OF CERAMICS AND METALS AS AN ENTRY POINT FOR THE DEVELOPMENT OF CONTEMPORARY JEWELLERY CRAFTS, International Journal of Design and Fashion Studies, Vol. 3, No. 1, 2020, pp. 10-13.

Received: August 12, 2020

Accepted: October 6, 2020 